\title{
KONSEP PERIZINAN TERPADU SEBAGAI UPAYA PENCEGAHAN TINDAK PIDANA KORUPSI SEKTOR PERTAMBANGAN
}

\begin{abstract}
Nurul Listiyani
${ }^{1}$ Fakultas Hukum Universitas Islam Kalimantan (UNISKA) MAAB Banjarmasin Jl. Adhyaksa No. 2, Banjarmasin E-mail: nurullistiyani5@gmail.com

Submitted : 28/02/2018 Reviewed 11/03/2018 Accepted:22/03/2018

Abstract:Legal issues raised related to the problem of unintegrated licensing in Indonesia which is one of the indicators caused by inconsistency in the application of environmental concept as its meaning and scope. With the unintegrated of licensing arrangements, then each sector has its own authority to regulate the requirements, procedures, timing and fees for licensing. Through a regulation and conceptual approach, the researcher examines the problematic licensing in mining activities that provides a gap in the occurrence of corruption. Non-integration makes the process of publishing mining permits long and complex. Licensing is integrated with fusion of competence which is carried out by means of coordination, it is working together in the exertion of autonomous competence. It is expected to be a step to prevent the occurrence of gratuity practices undertaken by the applicant of the mining business permit to the competent authority to issue the permit.
\end{abstract}

Keywords: Licensing; Mining; Corruption; Integration

Abstrak :Isu Hukum yang diangkat berkaitan dengan persoalan tidak terpadunya penyelenggaraan perizinan di Indonesia yang salah satu indikatornya disebabkan ketidakkonsistenan penerapan konsep lingkungan hidup sebagaimana makna dan ruang lingkupnya. Dengan ketidakterpaduan pengaturan perizinan tersebut, maka masing-masing sektor memiliki kewenangan sendiri untuk mengatur persyaratan, prosedur, waktu dan biaya pengurusan perizinan. Melalui pendekatan perudangundangan dan konseptual, peneliti mengkaji problematika perizinan dalam kegiatan pertambangan yang memberikan celah terjadinya tindak pidana korupsi tersebut. Ketidakterpaduan membuat proses penerbitan izin pertambangan yang panjang dan rumit. Perizinan yang terpadu dengan penyatuan wewenang (fusion of competence) yang dilaksanakan dengan cara koordinasi, yakni kerjasama dalam pelaksanaan wewenang yang bersifat mandiri (working together in the exertion of autonomous competences). diharapkan menjadi langkah untuk mencegah terjadinya praktek gratifikasi yang dilakukan oleh pemohon izin usaha 
pertambangan kepada pejabat yang berwenang untuk mengeluarkan izin tersebut.

Kata kunci : Perizinan; Pertambangan; Korupsi; Integrasi.

\section{PENDAHULUAN}

Negara dalam penguasaan atas SDA memiliki fungsi untuk membuat kebijakan, pengurusan, pengaturan, pengelolaan, dan pengawasan (Putusan Mahkamah Konstitusi Nomor 001-021-022/PUU-I/2003). Fungsifungsi tersebut termanifestasi dalam penjelasan Mahkamah Konstitusi sebagai berikut :

a. Fungsi pengurusan (bestuursdaad) oleh negara dilakukan oleh pemerintah dengan kewenangannya untuk mengeluarkan dan mencabut fasilitas perizinan (vergunning), lisensi (licentie), dan konsesi (concessie).

b. Fungsi pengaturan oleh negara (regelandaad) dilakukan melalui kewenangan legislasi oleh DPR bersama dengan pemerintah, dan regulasi oleh pemerintah (eksekutif).

c. Fungsi pengelolaan (beheersdaad) dilakukan melalui mekanisme pemilikan saham (share holding) atau melalui keterlibatan langsung dalam manajemen Badan Usaha Milik Negara atau Badan Hukum Milik Negara sebagai instrumen kelembagaan melalui mana negara c.q. Pemerintah mendayagunakan penguasaannya atas sumber-sumber kekayaan itu untuk digunakan bagi sebesar-besarnya kemakmuran rakyat.

d. Fungsi pengawasan oleh negara (toezichthoudensdaad) dilakukan oleh negara c.q. pemerintah dalam rangka mengawasi dan mengendalikan agar pelaksanaan penguasaan oleh negara atas cabang produksi yang penting atau yang menguasai hajat hidup orang banyak dimaksud benarbenar dilakukan untuk sebesar-besarnya kemakmuran rakyat.

Kekayaan keanekaragaman hayati dan sumber daya alam yang dikuasai oleh negara tersebut "melahirkan" tanggung jawab negara untuk melakukan perlindungan dan pengelolaannya. Pasal 2 huruf a Undang-Undang Nomor 32 Tahun 2009 tentang UUPPLH menyatakan bahwa perlindungan dan pengelolaan lingkungan dilaksanakan berdasarkan asas tanggung jawab negara. Tanggung jawab negara tersebut dimaknai sebagai berikut:

a. Negara menjamin pemanfaatan sumberdaya alam akan memberikan manfaatn yang sebesar-besarnya bagi kesejahteraan dan mutu hidup rakyat, baik generasi masa kini maupun generasi masa depan.

b. Negara menjamin hak warga negara atas lingkungan hidup yang baik dan sehat.

c. Negara mencegah dilakukannya kegiatan pemanfaatan sumber daya alam yang menimbulkan pencemaran dan/ atau kerusakan lingkungan hidup.

Dalam pengelolaan lingkungan hidup, upaya utama yang harus dilakukan adalah pencegahan pencemaran atau kerusakan lingkungan hidup, bukan penanggulangan pencemaran yang telah terjadi, sesuai dengan prinsip yang menyatakan "an ounce of prevention is worth a pound of cure". Salah satu tindakan preventif yang menjadi prinsip dalam Hukum Administrasi Negara adalah melalui prosedur perizinan. Fungsi preventif dari kegiatan usaha yang bersinggungan dengan lingkungan hidup diwujudkan dalam bentuk izin lingkungan yang dikeluarkan oleh pejabat 
yang berwenang. Selanjutnya izin lingkungan menjadi syarat utama untuk mengeluarkan izin usaha yang berkaitan dengan eksploitasi sumber daya alam, contohnya izin usaha pertambangan.

Otonomi daerah sebelum berlakunya Undang-Undang Nomor 23 tahun 2014 (Lembaran Negara RI Tahun 2014 Nomor 244, Tambahan Lembaran Negara RI Nomor 5587) tentang Pemerintahan Daerah, yang memberikan kewenangan kepada kepala daerah propinsi dan kabupaten/ kota untuk mengeluarkan izin usaha pertambangan, telah mengkondisikan kepala daerah menjadi "rajaraja kecil" di daerahnya.(Gunawan Sardjito, 2009). Izin Usaha Pertambangan mayoritas dikeluarkan oleh pemerintah kabupaten kota. Bahkan apabila pertambangan terjadi di lahan tapal batas (lintas) Kabupaten/ kota yang sebenarnnya menjadi kewenangan provinsi untuk mengeluarkan izin, maka biasanya akan "disiasati" dengan mengeluarkan 2 (dua) buah IUP masing-masing pemerintah daerah kabupaten/ kota.

Berdasarkan analisa PWYP (Publish What You Pay) Indonesia melalui telaah data yang dihasilkan dari Koordinasi dan Supervisi (Korsup) KPK bersama Kementerian ESDM dan pihak-pihak terkait, yang mencakup seluruh daerah kaya sumberdaya mineral dan batu bara (provinsi, kabupaten/bupati) di Indonesia. Dari data tersebut, diidentifikasi terdapat celah-celah potensi korupsi dalam tahapan dan proses perizinan tambang, sejak proses alih fungsi lahan, pemberian Izin Wilayah Usaha Pertambangan (WIUP), izin pencadangan/eksplorasi, hingga keluarnya izin produksi. ${ }^{1}$

1 https://pwyp-indonesia.org/id/153659/perizinantambang-sarat-potensi-korupsi/26/08/2016 diakses tanggal 06 Maret 2018
Agung Budiono, Manajer Advokasi untuk Korsup Energi PWYP Indonesia mengatakan, keempat contoh situasi di atas, merupakan pintu masuk yang diduga menjadi celah terjadinya potensi korupsi, baik melalui modus kick back (komisi), suap, maupun modus-modus korupsi lainnya.

\section{METODE}

\section{Jenis Penelitian}

Penelitian hukum yang memfokuskan kajian terhadap Problematika perizinan dalam kegiatan pertambangan yang memberikan celah terjadinya tindak pidana korupsi ini merupakan penelitian hukum dalam ranah kajian yuridis normatif atau doktrinal, yang menurut Peter Mahmud Marzuki merupakan proses untuk menemukan aturan hukum, prinsip-prinsip hukum, maupun doktrindoktrin hukum guna menjawab isu hukum yang dihadapi. ${ }^{2}$

\section{Pendekatan penelitian}

Dalam penelitian ini, penulis menggunakan 3 (tiga) pendekatan yang memiliki keterkaitan secara siginifikan, yaitu pendekatan perundang-undangan, pendekatan konseptual, dan pendekatan filosofis.

\section{Jenis dan Sumber Bahan Hukum}

Jenis bahan hukum yang digunakan dalam penelitian ini meliputi bahan hukum primer, bahan hukum sekunder, dan bahan hukum tersier. ${ }^{3}$ Dalam melakukan analisis terhadap isu hukum, maka sumber bahan hukum primer yang digunakan terdiri atas: Undang-

2 Peter Mahmud Marzuki. 2013. Penelitian Hukum (Edisi Revisi). Jakarta: Kencana Prenada Media Group, hlm. 35.

3 SoetandyoWignjosoebroto. 2002.Hukum Paradigma, Metode dan Dinamika Masalahnya. Jakarta: Huma, hlm. 14 
Undang Dasar Negara Republik Indonesia Tahun 1945 setelah Perubahan Keempat, Ketetapan Majelis Permusyawaratan Rakyat (Tap MPR) Nomor IX/MPR/2001 tentang Pembaruan Agraria dan Pengelolaan Sumber Daya Alam. Bahan hukum primer yang terdiri atas undang-undang yang mengatur secara khusus tentang lingkungan hidup, yakni: Undang-Undang Nomor 32 Tahun 2009 tentang Perlindungan dan Pengelolaan Lingkungan Hidup (Lembaran Negara Republik Indonesia Tahun 2009 Nomor 140, Tambahan Lembaran negara Republik Indonesia Nomor 5059). Peraturan perundang-undangan di bidang pertambangan, yakni Undang-Undang Nomor 4 Tahun 2009 tentang Pertambangan Mineral dan Batubara (Lembaran Negara Republik Indonesia Tahun 2009 Nomor 4, Tambahan Lembaran Negara Republik Indonesia Nomor 4959), serta Undang-Undang Nomor 31 Tahun 1999 tentang Tindak Pidana Korupsi. Sumber bahan hukum sekunder dan tersier juga ikut mendukung keakuratan penelitian yang penulis laksanakan.

\section{Teknik Pengumpulan Bahan Hukum}

Teknik pengumpulan bahan hukum dimaksudkan untuk memperoleh bahan hukum dalam penelitian dengan cara studi kepustakaan. Studi kepustakaan adalah suatu alat pengumpulan bahan hukum yang dilakukan melalui bahan hukum tertulis dengan mempergunakan content analysis. ${ }^{4}$

\section{Analisis Bahan Hukum}

Analisis yang dilakukan adalah dengan cara berpikir "order of logic", yang mengembangkan pola pikir berdasar dari analisis yang paling mendasar dan hakiki dan kepada anali-

4 Op. cit, hlm.21. sis yang bersifat materil. ${ }^{5}$ Langkah-langkah penelitian yang mendasar adalah pada saat melakukan refleksi terhadap asas dan nilai hukum yang terdapat dalam peraturan perundang-undangan yang menjadi dasar untuk melakukan analisis yuridis terhadap permasalahan.

\section{ANALISIS DAN PEMBAHASAN Pengelolaan Sumber Daya Alam Batubara}

Pengaturan pemanfaatan kekayaan alam didasarkan pada pasal 33 ayat (3) UUD NRI Tahun1945, "Bumi, air dan kekayaan alam yang terkandung di dalamnya dikuasai oleh negara dan digunakan untuk sebesar-besar kemakmuran rakyat". ${ }^{6}$ Amanat Pasal 33 ayat (3) UUD NRI Tahun 1945 mengandung asas yang mendasar, yakni asas maksimal yang tercermin dari kata sebesar-besarnya, sejalan dengan maksud penggunaannya yang dibatasi oleh asas kekekalan yanng tercermin dari kata rakyat, yang mengandung makna meliputi seluruh generasi Bangsa Indonesia yang keberadaan dan hubungannya dengan sumber kekayaan alam adalah abadi.

5 Anton F Susanto. 2007. Hukum dari Cosilence Menuju Paradigma Hukum Konstruktif Transgresif. Bandung: Refika Aditama, hlm. 63.

6 Notonegoro, menyatakan: "istilah yang perlu kita perhatikan di dalam Pasal 33 ayat (3) UUD NRI adalah istilah 'dikuasai' dengan tidak lebih dahulu mempunyai purbasangka tentang penafsiran daripada istilah-istilah ini, maka dari kenyataan terdapat dua macam istilah yaitu, 'dikuasai' dan 'dipergunakan'. Dalam pasal ini kiranya ditarik kesimpulan, bahwa harus diperbedakan antar dikuasai dan dipergunakan, dalam arti bahwa, dipergunakan itu sebagai tujuan dari dikuasai, meskipun kata kata penghubungnya itu 'dan' hingga nampaknya itu sebagi dua hal yang tidak ada sangkut pautnya dalam hubungan sebab akibat. Lihat Notonegoro: Politik Hukum dan Pembangunan Agraria di Indonesia”. Pancoran Tujuh. Jakarta. 
Sumber daya alam batubara tidak hanya dikuasai semata, namun ia juga harus diusahakan. Sumber daya alam batubara bukan hanya menjadi barang mati atau hanya menjadi harta karun yang tidak diolah. Ia harus dimanfaatkan agar potensinya dapat memberikan kemanfaatan bagi rakyat. Pengusahaan sumber daya alam umumnya padatahapawaldimaknaisebagaipengusahaan yang berdampak secara ekonomis, yaitu pendekatan atas pengusahaan sumber daya alam hanya pendekatan ekonomi semata. Namun perkembangan kebijakan dewasa ini menempatkan pengusahaan sumber daya alam tidak hanya sebatas pendekatan ekonomi, namun pendekatan nonekonomi pun menjadi prinsip yang melekat dalam pengusahaan sumber daya alam.

\section{Kewenangan Pengelolaan Pertambangan Mineral dan Batubara Menurut Undang- Undang Pemerintahan Daerah}

Undang-Undang Nomor 23 Tahun 2014 (Lembaran Negara Republik Indonesia Tahun 2014 Nomor 244, Tambahan Lembaran Negara Republik Indonesia Nomor 5587) tentang Pemerintahan Daerah, menempatkan urusan pemerintahan konkuren ${ }^{7}$ didasarkan pada prinsip akuntabilitas, efisiensi dan eksternalitas, serta kepentingan strategis nasional. ${ }^{8}$ Urusan pertambangan menjadi urusan pemerintahan konkuren pilihan. Ada 8 (delapan) urusan yang termasuk dalam urusan pemerintahan pilihan tersebut, yakni: kelautan dan perikanan, pariwisata, pertanian, kehutanan, energi dan sumber daya mineral, perdagangan, perindustrian, dan transmigrasi.

7 Urusan yang dibagi antara Pemerintah Pusat, Pemerintah Daerah Provinsi dan daerah Kabupaten/ Kota.
Dari 8 (delapan) urusan pemerintahan pilihan tersebut, khusus untuk 3 (tiga) jenis urusan pemerintahan pilihan, penyelenggaraannya hanya diserahkan kepada pemerintah pusat dan daerah provinsi. Ketiga urusan pemerintahan pilihan tersebut adalah: ${ }^{9}$

(1) Kelautan;

(2) Kehutanan; namun yang berkaitan dengan pengelolaan Taman Hutan Raya Kabupaten/Kota, menjadi kewenangan daerah Kabupaten/ Kota;

(3) Energi dan Sumber Daya Mineral (ESDM), namun yang berkaitan dengan pengelolaan minyak dan gas bumi, mejadi kewenangan Pemrintah Pusat. Sedangkan untuk urusan yang berkaitan dengan pemanfaatan langsung Panas Bumi dalam daerah Kabupaten/ Kota, menjadi kewenangan daerah Kabupaten/ Kota.

Terjadi perubahan yang sangat signifikan terhadap pola penyelenggaraan pengelolaan energi dan sumber daya mineral di Indonesia, termasuk pengelolaan sumber daya batubara. Perubahan drastis ini adalah ditandai dengan ditariknya kembali kewenangan daerah Kabupaten/ Kota dalam penyelenggaraan energi dan sumber daya mineral. Kewenangan dalam pengelolaan sumber daya energi dan mineral diselenggarakan oleh Pemerintah Pusat dan Pemerintah Provinsi.

Kewenangan Pengelolaan Tambang Mineral dan Batubara Menurut UU Minerba

Landasan filosofis ditetapkannya Undang-Undang Nomor 4 Tahun 2009 (Lembaran Negara Republik Indonesia Tahun 2009 Nomor 4, Tambahan Lembaran Negara Nomor 4959) tentang Pertambangan Mineral dan Batubara, yakni bahwa: "Mineral dan

9 Pasal 14 UU Nomor 23 Tahun 2014 
batubara yang terkandung dalam wilayah hukum pertambangan Indonesia merupakan kekayaan alam tak terbarukan sebagai karunia Tuhan Yang Maha Esa yang mempunyai peranan pengelolaannya harus dikuasai oleh negara untuk memberi nilai tambah secara nyata bagi perekonomian nasional dalam usaha mencapai kemakmuran dan kesejahteraan rakyat secara berkeadilan."

Tiga unsur esensial yang tercantum dalam landasan filosofis UU Nomor 4 Tahun 2009 tersebut adalah :

a. Eksistensi sumber daya mineral dan batubara;

b. Penguasaan negara; dan

c. Tujuan penguasaan negara.

Dari landasan filosofis tersebut tersirat makna tentang hakikat penguasaan negara atas sumber daya alam. Pengelolaan batubara merupakan upaya untuk mengurus, mengendalikan dan merumuskan kebijakan dalam pelaksanaan kegiatan pertambangan batubara.

Salim HS ${ }^{10}$ memberikan rumusan bahwa pengelolaan mineral dan batubara merupakan upaya untuk mengurus, mengendalikan, dan merumuskan kebijakan dalam pelaksanaan kegiatan pertambangan mineral dan batubara. Mengurus diartikan sebagai upaya untuk mengusahakan dan mengelola sumber daya mineral dan batubara. Sedangkan merumuskan kebijakan diartikan sebagai upaya untuk menyusun, membuat dan menetapkan berbagai peraturan perundang-undangan yang berkaitan dengan pemanfaatan sumber daya alam mineral dan batubara. ${ }^{11}$ Mengendalikan diimplementasikan pada upaya melaksanakan tindakan pencegahan dalam bentuk perizinan.

10 Salim HS.H. 2012. Hukum Pertambangan Mineral dan Batubara. Jakarta : Sinar Grafika, hlm. 55.

11 Ibid, hlm. 61-62.
Problematika Perizinan Dalam Pertambangan Batubara Yang Memberikan Celah Terjadinya Korupsi Sumber Daya Alam Konsep Perizinan

Perizinan merupakan bentuk jamak dari kata "izin" yang oleh Poerwadarminta diartikan dengan perkenan atau pernyataan mengabulkan tiada melarang, atau surat yang menyatakan "boleh melakukan sesuatu". ${ }^{12}$ Dalam Blak's Law Dictionary, izin (licence) berarti :

"a permit, granted by an appropriate govermental body, generally for a concideration, to a person, firm, or corporation to pursue some occuption or to carry on some business subject to regulation... A license is not a contract between the state and the license, but is a more peersonal permit."13

Pengertian izin menurut Spelt dan Ten Berge, adalah "Suatu persetujuan dari penguasa berdasarkan undang-undang atau peraturan pemreintah, untuk dalam keadaan tertentu menyimpang dari ketentuan-ketentuan larangan perundangan". ${ }^{14}$ Izin menurut Ateng Syafrudin berarti dan bertujuan menghilangkan halangan, atau hal yang dilarang menjadi boleh. ${ }^{15}$ Dengan memberi izin, pemerintah (Pejabat Tata Usaha Negara) memperkenankan orang yang memohonnya untuk melakukan tindakan-tindakan tertentu yang sebenarnya dilarang.

Izin adalah salah satu instrumen yang pal-

12 W.J.S.Poerwwadarminta.1964 Kamus Umum Bahasa Indonesia. Jakarta. Balai Pustaka, hlm. 390.

13 Henry Campbell Black. Op.cit,hlm. 920.

14 N Spelt dan J.B.J.M. ten Berge.1991. Pengantar Hukum Perizinan. Penyunting Phillipus M. Hadjon. Utrecht, hlm.3.

15 Ateng Syafrudin. Pengurusan Perizinan (Licensing Handling). Bandung. St. Aloysius,t.t., hlm. 9. 
ing banyak digunakan dalam hukum administrasi. Pemerintah menggunakan izin sebagai sarana yuridis untuk mengendalikan tingkah laku para warga. ${ }^{16}$ Perizinan merupakan bagian dari hubungan hukum antara pemerintah dengan masyarakat dalam rangka menjaga keseimbangan kepentingan masyarakat dengan lingkungannya dan upaya mewujudkan kepastian hukum bagi anggota masyarakat yang berkepentingan. ${ }^{17}$

Perizinan menurut Spelt dan ten Berge adalah izin dalam arti luas, sedangkan izin dalam arti sempit disebut "izin" saja. Izin (dalam arti sempit) selanjutnya dibedakan dengan bentuk-bentuk perizinan lainnya seperti dispensasi, konsesi, rekomendasi, tanda daftar, surat persetujuan, dan pendaftaran. ${ }^{18}$ Sejalan dengan pendapat tersebut, Tatiek Sri Djatmiati mengemukakan "Perizinan dapat berbentuk pendaftaran, rekomendasi, penentuan kuota, sertifikasi, dan izin melakukan suatu usaha". ${ }^{19}$

Menurut W.F. Prins dan R. Kosim Adisapoetro, izin diartikan dengan perbuatan pemerintah yang memperkenankan suatu perbuatan yang tidak dilarang oleh peraturan yang bersifat umum. ${ }^{20}$

Izin merupakan alat pemerintah yang bersifat yuridis preventif, dan digunakan sebagai instrumen administrasi untuk mengendalikan perilaku masyarakat. Izin bersifat preventif, karena dalam instrumen izin, tidak

16 N. M. Spelt. dan J. B. J. M. Ten Berge. Loc. Cit.

17 Ateng Syafrudin. Op. cit, hlm. 4

18 N.M.Spelt. dan J.B.J.M. ten Berge. Op. cit, hlm. $1-2$

19 Tatiek Sri Djatmiati. 2002 Prinsip Izin Usaha Industri di Indonesia. Disertasi Universitas Airlangga. Surabaya, hlm. 16.

20 W.F.Prins. dan R. Kosim Adisapoetro.1978 Pengantar Ilmu Hukum Adminsitrasi Negara. Jakarta: Pradnya Paramita, hlm. 72. bisa dilepaskan dengan perintah dan kewajiban yang harus ditaati oleh pemegang izin. ${ }^{21}$ Di sisi lain, izin berfungsi represif. Izin dapat berfungsi sebagai instrumen untuk menanggulangi masalah lingkungan disebabkan aktivitas manusia yang melekat dengan dasar perizinan.

Dalam kaitannya dengan kegiatan pertambangan mineral dan batubara, maka izin lingkungan adalah syarat mutlak yang harus dipenuhi penanggung jawab usaha untuk mendapatkan izin usaha, yang dikeluarkan oleh instansi sektor. Sehingga pada saat kegiatan pertambangan telah berlangsung, maka instansi sektor tersebut memiliki kewajiban untuk melakukan pengawasan terhadap pengelolaan lingkungan atas izin usaha pertambangan yang dikeluarkannya.

Konstruksi Pengaturan Izin Usaha Pertambangan Mineral dan Batubara

Penerbitan izin dalam melakukan kegiatan pertambangan terkait dengan makna yang terkandung dalam Pasal 33 ayat (3) UUD NRI 1945. Begitu pula dasar falsafah pengusahaan batubara yang diatur dalam UU Nomor 4 Tahun 2009 tentang Mineral dan Batubara, bersandar pada Pasal 33 ayat (3) UUD NRI 1945. Hal tersebut dinyatakan dalam UU Minerba bahwa "mineral dan batubara sebagai sumber daya alam yang terkandung di wilayah hukum pertambangan Indonesia, merupakan kekayaan alam yang dikuasai oleh negara untuk sebesar-besar kemakmuran rakyat. Namun untuk pengelolaannya diserahkan kepada pemerintah dan pemerintah daerah, yang berarti pula dalam penerbitan perizinannya berada di tangan pemerintah dan pemerintah daerah sesuai kewenangannya masing-masing.

21 N.H.T Siahaan. Op. cit, hlm. 239 
Pada dasarnya kegiatan pertambangan mineral dan batubara dapat diklasifikasi menjadi 2 (dua) macam, yakni illegal mining dan legal mining. ${ }^{22}$ Illegal mining merupakan kegiatan yang dilakukan oleh orang atau masyarakat tanpa adanya izin dari pejabat yang berwenang. Legal mining merupakan kegiatan pertambangan yang dilakukan oleh badan usaha atau badan hukum yang didasarkan pada izin yang dikeluarkan oleh pejabat yang berwenang.

Izin adalah suatu pernyataan atau persetujuan yang membolehkan pemegangnya untuk melakukan usaha pertambangan. Usaha pertambangan atau mining business merupakan "kegiatan dalam rangka pengusahaan mineral dan batubara yang meliputi tahapan kegiatan penyelidikan umum, eksplorasi, studi kelayakan (feasibility study), konstruksi, penambangan, pengolahan dan pemurnian, pengangkutan dan penjualan, serta kegiatan pasca tambang. ${ }^{23}$ Sedangkan pertambangan batubara adalah pertambangan endapan karbon yang terdapat di dalam bumi, termasuk bitumen padat, gambut, dan batuan aspal. UU Minerba mengadopsi beberapa bentuk perizinan, yakni:

a. Izin Usaha Pertambangan (IUP), mencakup IUP Eksplorasi dan IUP Operasi Produksi.

b. Izin Pertambangan Rakyat (IPR); dan

c. Izin Usaha Pertambangan Khusus (IUPK).

Permohonan untuk memperoleh IUP dapat diajukan oleh Badan Usaha, Koperasi, dan perseorangan. Badan Usaha adalah setiap badan hukum yang bergerak di bidang pertambangan yang didirikan berdasarkan hukum Indonesia dan berkedudukan dalam wilayah

22 Salim HS. 2014. Hukum Pertambangan Mineral dan Batubara.Jakarta: Sinar Grafika, hlm. 107.

23 Pasal 1 angka 7 UU Nomor 4 Tahun 2009.
Negara Kesatuan Republik Indonesia. ${ }^{24}$

IUP mempunyai hubungan yang sangat erat dengan wilayah Izin Usaha Pertambangan (selanjutnya ditulis WIUP), karena sebelum IUP diberikan kepada pemohon, maka yang harus dilakukan terlebih dahulu adalah menetapkan WIUP. Cara memperoleh WIUP mineral dan batubara adalah dengan cera lelang.

Syarat-Syarat Pemberian Izin Usaha Pertambangan (IUP)

Kegiatan pertambangan baru dapat dilakukan oleh pemohon setelah diterbitkannya IUP oleh pejabat yang berwenang. Untuk dapat diterbitkannya IUP, baik IUP Eksplorasi maupun IUP Operasi Produksi, maka pemohon IUP harus memenuhi persyaratan yang telah ditentukan dalam peraturan perundangundangan, yakni :
a. Administratif;
b. Teknis;
c. Lingkungan; dan
d. Finansial.

Seperti yang disebutkan di atas, bahwa salah satu persyaratan yang harus dipenuhi oleh pemohon IUP adalah persyaratan lingkungan. Persyaratan lingkungan ini terbagi menjadi 2 macam, yakni persyaratan lingkungan untuk memperoleh IUP eksplorasi dan persyaratan lingkungan untuk memperoleh IUP Operasi Produksi. Pemohon IUP Eksplorasi harus memenuhi persyaratan lingkungan, yakni dengan membuat pernyataan untuk memenuhi ketentuan peraturan perundang-undangan di bidang perlindungan dan pengelolaan lingkungan hidup. Sedangkan persyaratan lingkungan yang harus dipenuhi oleh pemohon IUP Operasi Produksi meliputi:

a. Pernyataan kesanggupan untuk mematuhi

24 Lihat Pasal 1 angka 32 UU Nomor 4 Tahun 2009 
ketentuan peraturan perundang-undangan di bidang perlindungan dan pengelolaan lingkungan hidup; dan

b. Persetujuan dokumen lingkungan hidup sesuai dengan ketentuan peraturan perundang-undangan. Dalam hal ini, jika dikaitkan dengan syarat untuk mendapatkan izin usaha yang ditetapkan dalam UU Nomor 32 Tahun 2009 tentang Perlindungan dan Pengelolaan Lingkungan Hidup adalah berupa izin lingkungan. Di mana izin lingkungan baru akan diterbitkan setelah pemohon izin memiliki dokumen keputusan kelayakan lingkungan hidup yang mengacu pada penilaian Amdal.

\section{Tipologi dan dan Teori yang Melatarbe- lakangi Tindak Pidana Korupsi}

Undang-Undang Nomor 32 Tahun 1999 sebagaimana diubah dengan Undang-Undang Nomor 20 Tahun 2001 tentang Pemberantasan Tindak Pidana Korupsi, mengelompokkan delik korupsi setidaknya, yakni:

a. Kelompok delik yang dapat merugikan keuangan negara atau perekonomian negara;

b. Kelompok delik penyuapan (aktif maupun pasif);

c. Kelompok delik penggelapan dalam jabatan;

d. Kelompok delik pemerasan dalam jabatan (knevelarij, extortion);

e. Kelompok delik pemalsuan;

f. Kelompok delik berkaitan dengan pemborongan, leveransir, dan rekanan;

g. Kelompok delik gratifikasi;

h. Kelompok delik yang merintangi dan menghalang-halangi penanganan perkara korupsi.

Selanjutnya dalam kesepakatan bersama antara Jaksa Agung Muda Tindak Pidana Ko- rupsi Khusus, Kepala Badan Resersi Kriminal Polri, Sekretaris Jenderal Komisi Pemberantasan Korupsi tanggal 29 Maret 2012 tentang pemetaan 10 (sepuluh) Area Rawan Korupsi Tahun 2012, telah ditentukan 10 (sepuluh) area rawan korupsi, yakni ${ }^{25}$ :

a. Pengadaan barang dan jasa pemerintah;

b. Keuangan dan perbankan;

c. Perpajakan;

d. Minyak dan gas;

e. BUMN dan BUMD;

f. Kepabean dan cukai;

g. Penggunaan APBN, APBD, dan APBNP ataupun APBDP;

h. Aset negara atau daerah;

i. Pertambangan; dan

j. Pelayanan umum.

Deskripsi area rawan korupsi sebagaimana tersebut di atas, tentu dapat berubah sesuai dengan dinamika pembangunan dan aktifitas atau dinamika masyarakat, pemerintah dan negara. Menurut Menteri Dalam Negeri, Tjahjo Kumolo ${ }^{26}$ mengingatkan tentang pentingnya memahami area rawan korupsi yang antara lain menyangkut perencanaan anggaran, penyimpangan belanja hibah dan bansos, pajak dan retribusi daerah, pengadaan barang dan jasa, belanja perjalanan dinas, perijinan serta jual beli jabatan yang saat ini menjadi trend korupsi. Dalam proses itu, acapkali terjadi kongkalikong yang berujung pada terjadinya tindak korupsi, entah itu suap, mark up atau gratifikasi.

Menjamurnya tindak pidana korupsi membuat gundah gulana segenap bangsa Indonesia karena secara faktual upaya-upaya

25 Bambang Waluyo. "Optimalisasi Pemberantasan Korupsi di Indonesia”.Jurnal Yuridis. Vol. 1 No. 2 Desember 2014. Hlm. 169-182.

26 https://faktualnews.co/2018/02/18/area-rawankorupsi-penjelasan-tjahjo-kumolo/66629/ 
untuk melakukan pencegahan telah dilaksanakan, baik berupa penetapan aturan-aturan maupun penetapan langkah-langkah strategis dalam rangka optimalisasi pemberantasan korupsi. ${ }^{27}$ Latar belakang mengapa dilakukannya tindak pidana korupsi mengandung jawaban yang multikompleks. Beberapa pendapat dan teori-teori menjelaskan timbulnya praktik korupsi, sebagai berikut:

\section{1) Teori Klitgaard}

Menurut Teori Robert Klitgaard, monopoli kekuatan oleh pimpinan (monopoly of power) ditambah dengan besarnya kekuasaan yang dimiliki (discretion of oficial) dan tanpa adanya pengawasan yang memadai (minus accountability), maka hal tersebut menjadi pendorong terjadinya korupsi. Perubahan sistem pemerintahan dari sentralistik menjadi otonomi daerah telah menggeser praktik korupsi yang dahulu hanya didominasi oleh pemerintah pusat (saat itu kekuasaan ada pada pemerintah pusat) kini menjadi marak terjadi di daerah (karena otonomi daerah telah memberikan kekuasaan kepada pimpinan di daerah). Hal ini selaras dengan Teori Klitgaard bahwa korupsi mengikuti kekuasaan.

2) Teori Ramirez Torez

Teori ini menyatakan bahwa korupsi adalah kejahatan kalkulasi atau perhitungan (crime of calculation) bukan hanya sekedar keinginan (passion). Seseorang akan melakukan korupsi jika hasil yang didapat dari korupsi lebih tinggi dan lebih besar dari hukuman yang didapat serta kemungkinan tertangkapnya yang relatif kecil.

3) Teori Jack Bologne (GONE)

Teori ini menyebutkan bahwa akar penyebab korupsi ada 4 (empat) hal, yaitu:

27 Bambang Waluyo. Op.cit.hlm. 170. a. Greedy (keserakahan), berkaitan dengan adanya perilaku serakah yang secara potensial ada pada diri setiap orang

b. Opportunity (kesempatan), berkaitan dengan keadaan organisasi atau instansi atau masyarakat yang sedemikian rupa sehingga terbuka kesempatan bagi seseorang untuk melakukan korupsi.

c. Need (kebutuhan), berkaitan dengan faktor-faktor yang dibutuhkan oleh individu-individu untuk menunjang hidupnya.

d. Exposures (pengungkapan), berkaitan dengan tindakan-tindakan atau hukuman yang tidak memberi efek jera pelaku maupun masyarakat pada umumnya.

4) Teori Vroom

Teori Vroom mendalilkan bahwa terdapat hubungan antara kinerja seseorang dengan kemampuan dan motivasi yang dimiliki. Berdasarkan Teori ini, kinerja (performance) seseorang merupakan fungsi dari kemampuannya (ability) dan motivasi (motivation). Kemampuan seseorang ditunjukkan dengan tingkat keahlian (skill) dan tigkat pendidikan (know-ledge) yang dimilikinya. Sehingga dengan tingkat motivasi yang sama seseorang dengan skill dan knowledge yang lebih tinggi akan menghasilkan kinerja yang lebih baik. Hal tersebut terjadi dengan asumsi variabel $\mathrm{M}$ (motivasi) adalah tetap. Tetapi dalam teori ini, Vroom juga membuat fungsi tentang motivasi, yaitu motivasi seseorang akan dipengaruhi oleh harapan (expectation) orang yang bersangkutan dan nilai (velue) yang terkandung dalam setiap pribadi seseorang. Jika harapan seseorang adalah ingin kaya, maka ada dua kemungkinan yang akan dia lakukan. Jika nilai yang dimiliki 
positif, maka dia akan melakukan hal-hal yang tidak melanggarhukum agar bisa menjadi kaya. Namun jika dia seseorang yang memiliki nilai negatif, maka dia akan berusaha mencari segala cara untuk menjadi kaya dan salah satunya dengan cara korupsi.

5) Teori Kebutuhan Maslow

Dalam teorinya, Maslow menggambarkan hierarki kebutuhan manusia dalam bentuk piramida. Semakin tinggi hierarki, kebutuhan tersebut semakin kecil keharusan untuk dipenuhi. Teori Kebutuhan Maslow tersebut menggambarkan hierarki kebutuhan dari paling mendasar (bawah) hingga naik paling tinggi yang merupakan aktualisasi diri. Kebutuhan paling mendasar dari seorang manusia adalah sandang dan pangan (physical needs). Selanjutnya kebutuhan keamanan adalah perumahan atau tempat tinggal. Kebutuhan sosial adalah berkelompok, bernasyarakat, berbangsa. Ketiga kebutuhan paling bawah adalah kebutuhan utama (Prime needs) setiap orang. Setelah kebutuhan utama terpenuhi, kebutuhan seseorang akan meningkat kepada kebutuhan penghargaan diri yaitu keinginan agar kita dihargai, berperilaku terpuji, demokratis dan lainnya. Kebutuhan paling tinggi adalah kebutuhan pengakuan atas kemampuan kita, misalnya kebutuhan untuk diakui sebagai pimpinan yang dipatuhi oleh bawahannya.

\section{Rekonstruksi Pengaturan Perizinan yang} Terpadu Sebagai Langkah Pencegahan Korupsi Pada Sektor Pertambangan

\section{Korupsi Pada Sektor Pertambangan}

Korupsi sudah dianggap sebagai penyakit moral, bahkan ada kecenderungan semakin berkembang dengan penyebab multifaktor. Oleh karena itu penanganannya perlu dilakukan secara sungguh-sungguh dan sistematis, dengan menerapkan strategi yang komprehensif - secara preventif, detektif, represif, simultan dan berkelanjutan dengan melibatkan semua unsur terkait, baik unsur-unsur Lembaga Tertinggi dan Tinggi Negara, maupun masyarakat luas. ${ }^{28}$

Pasal 3 Undang-Undang Nomor 31 Tahun 1999 tentang Tindak Pidana Korupsi mengatur bahwa sebuah perbuatan termasuk dalam tindak pidana korupsi apabila seorang Pegawai negeri/ penyelenggara negara menyalahgunakan kewenangan/ kesempatan/ sarana yang ada padanya karena jabatan/ kedudukan, untuk menguntungkan diri sendiri/ orang lain, yang dapat merugikan keuangan/ perekonomian negara.

Salah satu perbaikan yang harus ditangani adalah dalam proses perizinan. Hal ini disampaikan oleh Menteri PPN/ Kepala Bappenas, Bambang Brodjonegoro, pada sambutan Hari Anti Korupsi Sedunia (Harkodia) 2017, berkaitan dengan semakin maraknya korupsi yang terjadi pada sektor sumber daya alam. ${ }^{29}$ Menteri Bambang dalam sambutannya mengatakan sebagai tindaklanjut dari komitmen dan upaya untuk memberantas korupsi, baik melalui pencegahan dan penindakan, Pemerintah Indonesia telah menerbitkan Strategi Nasional Pencegahan dan Pemberantasan Korupsi (Stranas PPK) dengan Peraturan Presiden Nomor 55 Tahun 2012. Strategi ini

28 Tim Pengkajian SPKN.2002. Upaya Pencegahan Penanggualangan Korupsi Pada Pengelolaan Pegawai. Badan Pengawasan Keuangan dan Pembangunan.

29 https://www.bappenas.go.id/id/berita-dan-siaranpers/komitmen-pencegahan-dan-pemberantasankorupsi-telah-dijabarkan-ke-dalam-rkp-tahunan/ diakses tanggal 07 Maret 2018. 
merupakan langkah komprehensif dan holistik yang menjadi acuan bagi segenap pemangku kepentingan, sehingga pelaksanaan oleh baik Kementerian/Lembaga, maupun daerah tidak berjalan sendiri, sinergis baik dalam jangka panjang maupun menengah dan tahunan," tutur Menteri Bambang.

Kasus korupsi terkait izin tambang pada tahun 2017 yang melibatkan Bupati Konawe Utara, Sulawesi Tenggara, Aswad Sulaiman, adalah sebuah fakta tentang rentannya tindak pidana korupsi yang dilakukan berkaitan dengan perizinan. Dalam kerugian negara yang diduga mencapai 2,3 triliun tersebut, Aswad diduga menerima uang dari 8 (delapan) perusahaan tambang Nikel sebagai pemohon izin usaha pertambangan eksplorasi. ${ }^{30}$

Kasus tindak pidana korupsi yang berkaitan dengan perizinan selanjutnya yang melibatkan Bupati Kutai Kartanegara, Rita Widyasari, dan Komisaris PT. Media Bangun Bersama, Khairudin. Sumber penerimaan gratifikasi terbesar diperoleh dari para pemohon izin lingkungan dan SKKL. Gratifikasi ratusan miliar diterima oleh Rita, dalam kapasitasnya sebagai pejabat yang mengeluarkan izin lingkungan bagi perusahaan yang akan melaksanakan kegiatan yang berkaitan dengan lingkungan hidup, salah satunya adalah usaha pertambangan. ${ }^{31}$

Indikasi potensi korupsi sektor pertambangan beserta temuan-temuannya antara lain: (1) Terdapat WIUP dan IUP di wilayah hutan yang dilarang untuk kegiatan pertambangan, seperti hutan konservasi dan hutan lindung (khusus hutan lindung dengan model penambangan terbuka/open pit mining). Korsup KPK bersama Kementerian Lingkungan

30 Trbunnews.com. diakses pada tanggal 05 Maret 2018, pukul 13.15. Wita.

31 Ibid. diakses pukul 14.00 Wita
Hidup dan Kehutanan (LHK) mendata dari seluruh luasan IUP di kawasan hutan seIndonesia (26 juta hektar), 1,37 juta Hektar masih berada di Kawasan Hutan Konservasi, dan 4,93 juta Hektar berada di Kawasan Hutan Lindung-secara open pit mining. (2) Terdapat perusahaan yang tidak memiliki Nomor Pokok Wajib Pajak (NPWP), namun tetap mendapatkan IUP. Padahal perusahaan pemegang IUP seharusnya memiliki kelayakan (eligibility) yang baik, yang salah satunya ditunjukkan melalui kepemilikan NPWP. Ditjen Pajak mencatat, periode pajak 2010-2012 IUP yang tercatat baru sebanyak 7.834 IUP, dan dari total jumlah IUP tersebut yang memiliki NPWP hanya sekitar $76 \%$ atau 5.984 IUP. Artinya 24\% nya tidak memiliki NPWP. (3) Terdapat perusahaan yang tidak berkomitmen menyetor dana jaminan reklamasi dan pascatambang, namun tetap mendapatkan IUP. Padahal menurut ketentuan, komitmen dan alokasi dana jaminan dari perusahaan merupakan prasyarat untuk mendapatkan izin operasi produksi pertambangan. (4) Terdapat indikasi tumpang tindih izin (baik antar komoditas yang sama, maupun komoditas yang berbeda seperti antara izin sawit dan izin tambang). Korsup KPK menemukan persoalan tumpang tindih ini merupakan mayoritas penyebab dari status Non-Clean and Clear dari sebuah IUP, yang saat ini jumlahnya mencapa 4.023 IUP dari total 10.388 IUP di seluruh Indonesia. (5) Tunggakan pembayaran pajak dan penerimaan negara yang tidak diawasi dan ditagih dengan baik. Akibatnya, penerimaan negara menjadi tersendat dan dapat berpotensi menimbulkan kerugian negara jika tunggakan tersebut tidak ditagih. Data Kementerian ESDM mencatat, hingga kini tunggakan baik dari pemegang kontrak karya maupun pemegang IUP besarnya mencapai 25 Triliun Ru- 
piah. $^{32}$

Di samping perizinan, potensi tindak pidana korupsi sumber daya alam juga dapat terjadi karena eksploitasi dan pemanfaatan sumber daya alam yang tidak terukur. Lais $\mathrm{Abid}^{33}$ mengungkapkan bahwa indikasi suap dan manipulasi penerimaan negara dilakukan penyelenggara negara di tingkat nasional maupun daerah, di mana caranya adalah melalui sektor penerimaan yang harusnya masuk ke kas negara namun justru mengalir ke segelintir oknum birokrat atau swasta. Indikasi lainnya juga terjadi suap untuk memudahkan proses perizinan, misalnya diterbitkannya izin usaha pertambangan atas wilayah usaha pertambangan yang terletak dalam kawasan hutan lindung. Selanjutnya Lais Abid menyebutkan bahwa korupsi sumber daya alam dapat merugikan negara secara ekonomi dan ekologi.

\section{Konsep Perizinan Terpadu}

Persoalan keterpaduan dalam sistem perizinan bidang lingkungan hidup muncul karena tidak konsistennya penerapan konsep lingkungan hidup sebagaimana makna dan ruang lingkupnya. Padahal jika penerapan konsep lingkungan hidup konsisten dengan pengaturan sektor lingkungan hidup, maka akan mencerminkan dan sekaligus mampu melaksanakan keterpaduan dalam perlindungan dan pengelolaan lingkungan hidup.

Tidak konsistennya antara konsep lingkungan hidup, pengelolaan lingkungan hidup dan ruang hukum lingkungan, baik dalam pengaturan bidang sektoral lingkungan hidup maupun dalam praktik, mengakibatkan keti-

32 https://pwyp-indonesia.org/id/153659/perizinantambang-sarat-potensi-korupsi/26/08/2016 diakses tanggal 06 Maret 2018

33 Staf Divisi Investigation Indonesia Corruption Watch (ICW). dakterpaduan dalam penyelenggaraan perizinan. Ketidakterpaduan sistem perizinan bidang lingkungan hidup dapat telihat, yakni: ${ }^{34}$ pertama, pengaturan mengenai izin-izin sektoral diatur dalam undang-undang tersendiri dan mengutamakan kepentingan ekonomi. Sementara untuk mencapai pembangunan berkelanjutan seperti yang dijabarkan dalam penjelasan Pasal 1 angka 3 UUPPLH, diamanatkan keseimbangan antara kepentingan ekonomi, ekologi, dan sosial. Kedua, UUPPLH yang mengatur lingkungan hidup dan seharusnya menjadi pedoman bagi penyelenggaraan perizinan sektoral, justru berdiri sendiri. Hal tersebut terjadi karena dalam sistem peraturan perundang-undangan di Indonesia ${ }^{35}$ kedudukan UUPPLH sederajad dengan UU sektor lainnya seperti UU pertambangan Mineral dan Batubara.

Dengan ketidakterpaduan pengaturan perizinan tersebut, maka masing-masing sektor memiliki kewenangan sendiri untuk mengatur persyaratan, prosedur, waktu dan biaya pengurusan perizinan. Ketidakterpaduan ini membuat proses penerbitan izin pertambangan yang panjang dan rumit. Hal inilah yang kemudian menimbulkan celah terjadinya praktek suap yang dilakukan oleh pemohon izin usaha pertambangan kepada pejabat yang berwenang untuk mengeluarkan izin tersebut. Panjangnya proses penerbitan izin membuat pemohon izin melakukan gratifikasi ${ }^{36}$ dengan tujuan untuk mempermudah mendapatkan izin pertambangan. Gratifikasi yang dilaku-

34 Helmi. Loc.cit, hlm. 228

35 Pasal 7 UU Nomor 12 Tahun 2011 tentang Pembentukan Peraturan Perundang-undangan.

36 Pemberian dalam arti luas, meliputi pemberian uang, barang, rabat (discount), komisi, pinjaman tanpa bunga, tiket perjalanan, fasilitas penginapan, perjalanan wisata, pengobatan cuma-cuma, dan fasilitas lainnya. 
kan kepada pegawai negeri sipil/ penyelenggara negara yang berhubungan dengan jabatan/ kedudukannya dianggap sebagai suap.

Dalam Teorinya, Teori Jack Bologne (GONE) menyebutkan bahwa akar penyebab korupsi ada 4 (empat) hal, yaitu greedy (keserakahan), opportunity (kesempatan), need (kebutuhan), dan exposures (pengungkapan). Dalam penerbitan izin pertambangan, faktor opportunity (kesempatan) yang berkaitan dengan keadaan organisasi atau instansi atau masyarakat yang sedemikian rupa yang membuka kesempatan bagi seseorang untuk melakukan korupsi. Keadaan penerbitan izin usaha pertambangan yang panjang dan rumit telah membuka kesempatan seseorang untuk melakukan korupsi.

Integrasi berasal dari bahasa Inggris integration yang berarti kesempurnaan atau keseluruhan. Definisi konsep integrasi secara gramatikal berdasarkan Kamus Besar Bahasa Indonesia Pusat Bahasa adalah pembauran sehingga menjadi kesatuan yang utuh dan bulat. ${ }^{37}$ Selanjutnya menurut Achmad Maulana, ${ }^{38}$ integrasi memiliki 2 (dua) pengertian, yakni: pertama, pengendalian terhadap konflik atau penyimpangan tertentu. Kedua, membuat suatu keseluruhan dan menyatukan unsur-unsur tertentu. Sedangkan pengertian keterpaduan menurut Kamus Besar Bahasa Indonesia tidak diberikan makna secara gramatikal. Keterpaduan diartikan dalam kata benda sebagai "perihal terpadu".

Secara konseptual, kedua pengertian di atas, yakni pengertian keterpaduan dan integrasi, jelas menunjukkan ruang lingkup ling-

37 Departemen Pendidikan Nasional. Kamus Besar Bahasa Indonesia Pusat Bahasa. Jakarta : Gramedia Pustaka Utama.. hlm.541.

38 Achmad Maulana. 2004. Kamus Ilmiah Populer Lengkap. Yogyakarta: Absolut, hlm.173. kungan hidup yang bersifat integral (satu kesatuan/ terpadu). Konsep tersebut kemudian berkonsekuensi pada ruang lingkup pengelolaan lingkungan hidup, termasuk ruang lingkup sistem perizinan di bidang pemanfaatan lingkungan hidup, seperti perizinan pertambangan.

Perizinan terpadu merupakan instrumen hukum lingkungan yang manfaatnya ditentukan oleh penyelenggaraan sistem dalam perizinan itu sendiri. Jika perizinan hanya dimaksudkan sebagai sumber pendapatan bagi pemerintah, akan menimbulkan dampak negatif bagi lingkungan hidup dan membuka celah terjadinya tindak pidana korupsi.

UUPPLH sebagai norma hukum yang mengatur lingkungan hidup, mengenal 2 (dua) jenis izin, yakni izin lingkungan dan izin usaha dan/ atau kegiatan. Kedua jenis izin ini termasuk dalam ruang lingkup dan tunduk pada UUPPLH. Izin lingkungan itu sendiri menurut Pasal 40 ayat (1) UUPPLH menjadi persyaratan untuk memperoleh izin usaha dan/ atau kegiatan. Izin usaha dan/ atau kegiatan sebagaimana yang dimaksud dalam UUPPLH adalah izin untuk melakukan pengelolaan sumber daya lingkungan hidup, termasuk di dalamnya adalah pemanfaatan sumber daya mineral dan batubara. Dalam pengaturannya, pemanfaatan sumber daya alam diatur secara sektoral sehingga "seolaholah" dipisahkan dari pengaturan lingkungan hidup. ${ }^{39}$ Padahal jika dicermati dari pasalpasal yang mencerminkan keterpaduan dalam UUPPLH seperti yang diuraikan di atas,

39 Lihat Undang-undang sektoral yang mengatur pemanfaatan sumber daya alam seperti UU Nomor 4 Tahun 2009 tentang Pertambangan Mineral dan Batubara, UU Nomor 41 Tahun 1999, tentang Kehutanan, UU Nomor 22 Tahun 2001 tentang Minyak dan Gas Bumi, UU Nomor 18 Tahun 2004 tentang Perkebunan, dan lain-lain 
keterpaduan tersebut meliputi keterpaduan unsur lingkungan hidup, keterpaduan dalam pengelolaan dan keterpaduan stakeholders.

Salah satu fakta yuridis terjadinya pemisahan bidang urusan yang berkaitan dengan lingkungan hidup adalah dalam agenda Pengelolaan lingkungan Hidup Kementerian Lingkungan Hidup yang membagi bidang-bidang lingkungan hidup yakni kehutanan, kelautan, energi, sumber daya mineral dan pertambangan, lingkungan hidup, serta meteorologi dan geofisika. ${ }^{40}$ Menurut Katili ${ }^{41}$, sumber daya alam yang berbeda, kebijakan pengelolaannya secara terpisah namun keaneka ragaman sumber daya alam itu harus dipertimbangkan dalam merumuskan kebijakan yang terpadu dan menyeluruh, termasuk dalam pengaturan perizinan dalam pertambangan batubara yang melibatkan instansi sektor.

Idealnya, keterpaduan perizinan yang dimaksud oleh peneliti adalah penyatuan dari wewenang (fusion of competence) yang dilaksanakan dengan cara koordinasi, yakni kerjasama dalam pelaksanaan wewenang yang bersifat mandiri (working together in the exertion of autonomous competences). ${ }^{42}$ Keterpaduan horisontal menjamin adanya keserasian hubungan antar sektor, agar hasil yang diperoleh merupakan upaya bersama yang memperhitungkan banyak kepentingan yang terkadang saling berbenturan satu

40 Agenda "Arah Kebijakan Pengelolaan Lingkungan Hidup Tahun 2009.

41 Sumber Alam Untuk Kesejahteraan dan Ketahanan Nasional, dalam buku Biografi Prof. J.A. Katili.2007. Harta Bumi Indonesia. Penerbit PT. Grasindo.

42 A.V. Van den Berg. Integrated Licencing System and Procedures, Integration vs Coordination. Environmental Legislation Course. Puncak. September 1985. sama lain. Keterpaduan vertikal merupakan keserasian antara pelaksanaan kebijaksanaan dan program pemerintah pusat dengan pemerintah daerah.

\section{PENUTUP}

Ketidakterpaduan pengaturan perizinan dalam pertambangan batubara yang terindikasi dari kewenangan yang diatur secara sektoral dalam hal persyaratan, prosedur, waktu dan biaya pengurusan perizinan membuat proses penerbitan izin pertambangan yang panjang dan rumit. Hal inilah yang kemudian menimbulkan celah terjadinya praktek suap yang dilakukan oleh pemohon izin usaha pertambangan kepada pejabat yang berwenang untuk mengeluarkan izin tersebut. Panjangnya proses penerbitan izin membuat pemohon izin melakukan gratifikasi ${ }^{43}$ dengan tujuan untuk mempermudah mendapatkan izin pertambangan. Gratifikasi yang dilakukan kepada pegawai negeri sipil/ penyelenggara negara yang berhubungan dengan jabatan/ kedudukannya dianggap sebagai suap.

Perlu dikembangkan satu sistem hukum pengelolaan sumber daya alam yang jelas, tegas dan menyeluruh guna menjamin kepastian hukum sebagai landasan bagi upaya pengelolaan, salah satunya adalah pengelolaan dalam bentuk perizinan. Sistem perizinan yang terpadu dalam pertambangan merupakan penyatuan dari wewenang (fusion of competence) yang dilaksanakan dengan cara koordinasi, yakni kerjasama dalam pelaksanaan wewenang yang bersifat mandiri (working together in the exertion of

43 Pemberian dalam arti luas, meliputi pemberian uang, barang, rabat (discount), komisi, pinjaman tanpa bunga, tiket perjalanan, fasilitas penginapan, perjalanan wisata, pengobatan cuma-cuma, dan fasilitas lainnya. 
autonomous competences).

\section{BIBLIOGRAFI}

Danusaputro. St. Munajat. 1980. Hukum Lingkungan (BUKU I). Bandung: Binacipta.

Gautama. Sudargo. 1983. Pengertian Tentang Negara dan Hukum. Bandung : Alumni. Cetakan ke- 3.

A.V. van den Berg. 1985. Integrated Licencing System and Procedures, Integration vs Coordination. Environmental Legislation Course: Puncak.

De Haan. P. (et al). 1986. Bestuursrecht In De Social Rechtstaat. Deel I Ontwikkeling. Kluwer-Deventer : Organisatie Instrumentarium

Rangkuti. Siti Sundari. 1987. Hukum Lingkungan dan kebijakan Lingkungan dalam Proses Pembangunan Hukum Nasioanl Indonesia. Desertasi. Surabaya : UNAIR.

Rahardjo. Satjipto. 1991. Ilmu Hukum. Bandung : PT. Citra Aditya Bakti. Edisi Revisi.

Rangkuti. Siti Sundari. 1992. Pengantar Hukum Perizinan Lingkungan. Kerjasama Hukum Indonesia-Belanda.

Suparni. Ninik. 1994. Pelestarian Pengelolaan dan Penegakan Hukum Lingkungan. Jakarta : sinar Grafika. Cet. Ke II

Farida Indrati Soeprapto. Maria. 1998. Ilmu Perundang-Undangan. "Dasar-dasar dan Pembentukannya. Yogyakarta : Kanisius.

Hardjasoemantri. Koesnadi. 2002. Hukum Tata Lingkungan. Yogyakarta : Gajah Mada University Press. Cetakan ketujuhbelas.

Rizal Mustansyir. 2002. "HAM dalam Tinjauan Filsafat Analitik”. Pusat Studi
Hukum dan Kebijakan Indonesia: Jakarta Jurnal Hukum Jentera. Edisi 1 Tahun 1

Saleng. Abrar. 2004. Hukum Pertambangan. Cet. I. Yogyakarta : UII Press

Manan. Bagir. 2004. Menyongsong Fajar Otonomi Daerah. Yogyakarta : Pusat Studi Hukum Fakultas Hukum UII. Cet III.

Suhirman. Desentralisasi dan ekonomi Politik Perizinan : Mengambil Hak Yang Terampas. Sebagaimana disuntimg oleh Pradjarta Dirjosnjoto dan Herudjati Purwoko. 2004. Desentralisasi dalam Perspektif Lokal. Salatiga : Pustaka Percik.

Katili, J.A. 2007. Sumber Alam Untuk Kesejahteraan dan Ketahanan Nasional, dalam buku Biografi Prof. J.A. Katili; Harta Bumi Indonesia. Penerbit PT. Grasindo

Mahfud MD. 2007. Perdebatan Hukum Tata Negara Pasca Amandemen Konstitusi. LP3S: Jakarta.

Wignjosoebroto, Soetandyo. Hak-hak Manusia Yang Asasi Untuk Memperoleh Jaminan Rasa Aman dan Sejahtera Dalam Kehidupan Ekosob di Tengah Pelaksanaan Program Pembangunan Nasional yang Sering Tak Berkiblat Pada Kepentingan Rakyat. Makalah pada Workshop "Memperkuat Justisiabellitas Hak-hak Ekosob : Prospek dan Tantangan”. PUSHAM UII : Yogyakarta. 13-15 November 2007

Edie Toet Hendratno. 2009. Negara Kesatuan, Desentralisasi, dan Federalisme. Graha Ilmu: Yogyakarta.

Rahmadi, Takdir. 2013. Hukum Lingkungan di Indonesia. Rajawali Pers: Jakarta

Emil Salim. 1991. Pembangunan Berkelanjutan (Strategi Alternatif 
dalam Pemban gunan Dekade Sembilan puluhan). Artikel pada Prisma Majalah Pemikiran Sosial Ekonomi. LP3ES: Jakarta.

Naskah Akademik Undang-Undang Nomor 4 tahun 2009 tentang Mineral dan Batubara.

Naskah Akademik Undang-Undang Nomor 32 Tahun 2009 tentang Perlindungan dan Pengelolaan Lingkungan Hidup.

Franki Butar-Butar. 2010. Penegakan Hukum Lingkungan di bidang Pertambangan. Disertasi. Universitas Gajah Mada.

IUCN Environmental Law Programme. Draft International Covenant on Environmenntal and Development.

Fenty U. Puluhuwa. Disertasi. 2011. Pengawasan Sebagai Instrumen Penegakan Hukum Pada Pengelolaan Usaha Pertambangan Mineral dan Batubara. Univ. Negeri Gorontalo.

Syaifudin. 2012. Asas Keseimbangan dalam Perjanjian Kerjasama Penambangan Batubara. Disertasi Universitas 17 Agustus 1945 Surabaya.

A'an Efendi. 2012. "Prinsip-Prinsip Pengelolaan Pertambangan Berbasis Lingkungan Berdasar Undang-Undang Dasar Negara Republik Indonesia Tahun 1945". Jurnal Konstitusi. PKHK: Universitas Janabadra kerja sama dengan Mahkamah Agung Republik Indonesia. Vol. 1. No. 1.

Istislam. 2012 .Sanksi Paksaan Pemerintah Dalam Perlindungan Dan Pengelolaan Lingkungan Hidup. Disertasi. Universitas Airlangga: Surabaya

Ronny Adrie Maramis. 2013. Tanggung Jawab Pemulihan Lingkungan dalam Kegiatan Pertambangan Mineral dan Batubara. Disertasi. Universitas Hasanuddin: Makasar.
Naskah Akademik Undang-Undang Nomor 23 Tahun 2014 tentang Pemerintahan Daerah.

Bambang Waluyo. 2014. "Optimalisasi Pemberantasan Korupsi di Indonesia”. Jurnal Yuridis. Vol. 1 No. 2 Desember 2014.

Mas Achmad Santosa. 2014. Efektivitas Penegakan Hukum Administrasi dalam Perlindungan dan Pengelolaan Lingkungan Hidup di Indonesia: Studi Kasus di Provinsi Jawa Tengah. Disertasi. Universitas Indonesia: Jakarta.

NurulListiyani. 2016.'DampakPertambangan Terhadap Lingkungan di Kalimantan Selatan dan Implikasinya Bagi Hak-Hak Warga Negara". Jurnal Al Adl. Vol. 9 No.1.

Listiyani, Nurul. 2017. Pengaturan Pengawasan Pengelolaan Lingkungan Hidup Terhadap Tambang Batubara Dalam Perlindungan dan Pengelolaan Lingkungan Hidup. Disertasi. Universitas Brawijaya.

https://www.bappenas.go.id/id/beritadansiaran-pers/komitmen-pencegahandanpemberantasan-korupsi-telahdijabarkanke-dalam-rkp-tahunan/

https://faktualnews.co/2018/02/18/ arearawan-korupsi-penjelasan-tjahjokumolo/66629/.

ht tp $s: / /$ so e tandyo.wordpress. com/2010/08/19/mengkaji-danmenelitihukum-dalam-konsepnyasebagai-realitas-sosial/

http://www.mahkamahkonstitusi.go.id/index. php? page $=$ web. Berita\&id $=1142 \#$. VcmPNXHtlHw

www.wikipedia.org. Vitzhaw. Pengertian Koordinasi

Paraturan Perundang-Undangan 
Undang-Undang Dasar Negara Republik Indonesia Tahun 1945

Undang-Undang Nomor 20 Tahun 2001 tentang Pemberantasan Tindak Pidana Korupsi

Undang-Undang Nomor 32 Tahun 2009 tentang Perlindungan dan Pengelolaan Lingkungan Hidup;

Undang-Undanng Nomor 4 Tahun 2009 Tentang Pertambangan Mineral dan Batubara

Undang-Undang Nomor 12 Tahun 2011 tentang Pembentukan Peraturan Peraturan Perundang-undangan

Peraturan Pemerintah Nomor 27 tahun 2012 tentang Izin Lingkungan

Undang-Undang Nomor 23 Tahun 2014 tentang Pemerintah Daerah; 